\title{
CORRECTION
}

\section{Correction to: Modelling and Control of Nine-Switch Converter-Based DFIG Wind Power System}

\author{
DongLiang Liu ${ }^{1} \cdot$ Xu Zhang $^{1}\left(\mathbb{D} \cdot\right.$ Lei Pan $^{2} \cdot$ Aqiang $^{\mathrm{Li}^{1}}$
}

Published online: 8 February 2021

(c) The Korean Institute of Electrical Engineers 2021

\section{Correction to: \\ Journal of Electrical Engineering \& Technology (2020) 15:2587-2599 \\ https://doi.org/10.1007/s42835-020-00506-6}

Unfortunately the funding note has been omitted.

National Natural Science Foundation of China, NVH global optimization and control of electric vehicle electric power system under multiple service behaviors, fund approval number: 51877059.

Publisher's Note Springer Nature remains neutral with regard to jurisdictional claims in published maps and institutional affiliations.

The original article can be found online at https://doi.org/10.1007/ s42835-020-00506-6.

Xu Zhang

zx_hdu@163.com

1 College of Automation, Hangzhou Dianzi University, Hangzhou, China

2 School of Control and Mechanical Engineering, Tianjin Chengjian University, Tianjin, China 